\title{
Mercury Emissions Control from Existing Utility and Industrial Boilers
}

\author{
Jack A. Fuller ${ }^{*}, 1$ and A.B.M.S. Khan ${ }^{2}$ \\ ${ }^{1}$ College of Business and Economics, West Virginia University, USA \\ ${ }^{2}$ Department of Mechanical and Aerospace Engineering, College of Engineering and Mineral Resources, West Virginia \\ University, Morgantown, WV 26506, USA
}

\begin{abstract}
Industrial, commercial, and institutional (ICI) boilers are one of the major sources of hazardous air pollutants (HAP), including mercury (Hg). Coal-fired electric power plants constitute the largest point source of anthropogenic $\mathrm{Hg}$ in the United States. The primary objective of this paper was to address the mercury side of the boiler maximum achievable control technology (MACT) of the national emission standards for hazardous air pollutants (NESHAP). This paper analyzed data collected by a research team at West Virginia University (WVU) as part of a Mercury Emissions Research project. The research focused on solid fuel (coal) fired boilers covered by the industrial boilers MACT. Hg emissions data along with coal and stack analysis were collected through a combination of surveys and personal contact with appropriate individuals at these facilities. The collected data were analyzed to determine the applicability of $\mathrm{Hg}$ control technologies to ICI boilers and their emissions reduction capabilities.
\end{abstract}

Keywords: ICI boilers, mercury emissions, control technologies.

\section{INTRODUCTION}

Boilers are an integral part of coal-fired electric power plants and any other plants that need a supply of steam for heating, drying, sterilization, and other purposes. About 50\% of electricity generated in the United States comes from coalfired electric power plants [1]. When coal is combusted in a boiler, it primarily produces carbon dioxide $\left(\mathrm{CO}_{2}\right)$, oxides of nitrogen (NOx), sulfur dioxide $\left(\mathrm{SO}_{2}\right)$, and particulate matter (PM). Industrial, commercial, and institutional (ICI) boilers are one of the major sources of hazardous air pollutants (HAP), including mercury $(\mathrm{Hg})$. Coal-fired electric power plants constitute the largest point source of unregulated $\mathrm{Hg}$ emissions in the United States [2-4]. It has been estimated that about forty-eight tons of $\mathrm{Hg}$ is emitted from coal-fired power plants in the United States annually, which is about one percent of the total world wide $\mathrm{Hg}$ emissions [5].

Coal combustion in boilers produces $\mathrm{Hg}$ in three different forms in varying percentages. They are elemental mercury, oxidized mercury, and mercury that is adsorbed to particulates. Elemental mercury can travel a significant way in the atmosphere before being deposited to land and water bodies. Long term exposure to elemental mercury by humans has been shown to affect their central nervous system. Oxidized mercury in the presence of chlorine forms mercuric chloride $\left(\mathrm{HgCl}_{2}\right)$. Exposure to $\mathrm{HgCl}_{2}$ has been shown to result in tumors in experimental animals. Organic $\mathrm{Hg}$ compounds are formed when $\mathrm{Hg}$ combines with carbon. Methyl mercury is the most common organic $\mathrm{Hg}$ compound found in the environment [6]. Americans are primarily exposed to methyl mercury by eating contaminated fish.

\footnotetext{
*Address correspondence to this author at the Division of Business and Economics, West Virginia University, Morgantown, WV 26506-6025, USA; Tel: +304-293-7935; Fax: +304-293-8905; E-mail: jfuller@wvu.edu
}

A number of steps have been initiated to reduce emissions of $\mathrm{Hg}$ and to limit its exposure. Both the Clean Air Act (CAA) and the Clean Water Act (CWA) regulate Hg by establishing technology based standards for sources that emit mercury. The U.S. Environmental Protection Agency (USEPA) on September 13, 2004, developed national emission standards for hazardous air pollutants (NESHAP) for ICI boilers and process heaters. The NESHAP focused on "the maximum degree of reduction in hazardous air pollutants (HAP), including $\mathrm{Hg}$, that is achievable, taking into consideration the cost of achieving the emissions reductions, any non air quality health and environmental impacts, and energy requirements" [7]. This level of control is commonly referred to as maximum achievable control technology (MACT). The USEPA on March 15, 2005, also promulgated the Clean Air Mercury Rule (CAMR) to permanently cap and significantly reduce $\mathrm{Hg}$ emissions from coal-fired power plants in two phases. The first phase, which begins in 2010, aims to reduce $\mathrm{Hg}$ emissions down to thirty-eight tons a year and will take advantage of co-benefit reductions - that is $\mathrm{Hg}$ reductions achieved by reducing $\mathrm{SO}_{2}$ and NOx from coalfired power plants under the Clean Air Interstate Rule (CAIR) [8]. In the second phase, due in 2018, $\mathrm{Hg}$ emission is expected further to be reduced by $70 \%$ from the present level. During the second phase all coal-fired power plants will be subjected to a 'second cap' which will reduce $\mathrm{Hg}$ emissions to fifteen tons per year. New coal-fired power plants will also be subjected to stringent emission standards.

$\mathrm{Hg}$ emissions from ICI boilers are presently controlled by the existing conventional air pollution control devices (APCD) used to remove $\mathrm{NOx}, \mathrm{SO}_{2}$, and PM from combustion flue gas. This includes the capture of particulate bound $\mathrm{Hg}$ in PM control equipment and the capture of oxidized $\mathrm{Hg}$ compounds in wet flue gas desulfurization (FGD) systems [9]. In 1999-2000, USEPA conducted an Information Collection Request (ICR) to update the $\mathrm{Hg}$ emissions inventory for 
coal-fired power plants. It was found that the capture of $\mathrm{Hg}$ across existing APCD s varied significantly. Coal properties including chlorine content, sulfur content, flue gas temperature, ash content, and specific APCD configurations were likely to contribute to this variation. The level of control was found to range from $0 \%$ to more than $100 \%$ [10]. Therefore, there was clearly a need to determine if the existing fleet of ICI boilers can meet the new MACT regulations.

This paper reports survey data collected by a research team at West Virginia University (WVU) as part of a Mercury Emissions Research project. The research focused on coal-fired boilers covered by the industrial boilers MACT. $\mathrm{Hg}$ emissions data along with coal and stack analysis were collected through a combination of surveys and personal contact. The collected data were analyzed to determine the applicability of $\mathrm{Hg}$ control technologies to ICI boilers and their emissions reduction capabilities. The unique findings of this survey are expected help the researchers and policymakers projecting the control technologies employed by ICI boilers to capture $\mathrm{Hg}$ emissions and their effectiveness.

\section{INDUSTRIAL AND UTILITY BOILERS}

Boilers burn fuel and produce steam, which acts as the working fluid for power plants. Power plants generally employ utility boilers for steam production, while industrial boilers are used to produce steam for heating, drying, sterilization, etc. According to a Council of Industrial Boiler Owners (CIBO) report published in 2003, there were about 4,000 utility boilers and about 70,000 industrial boilers in operation in the United State [11]. The major differences between utility and industrial boilers can be categorized in three distinct areas: boiler size, boiler steam production and its application, and boiler design. Industrial boilers are much smaller in size, as compared to utility boilers. A typical utility boiler can produce about 3,500,000 pounds of steam per hour while steam production from the majority of industrial boilers may range from 10,000 to $1,200,000$ pounds of steam per hour. The size of the utility boilers allows them to have significant economies of scale, especially in the control of emissions that simply are not available to industrial boilers.

Utility boilers are primarily large field erected pulverized coal, oil, or natural gas fired high pressure, high temperature boilers with relatively uniform design and similar fuel combustion systems. In contrast, industrial boilers are large or small field erected or shop assembled package boilers designed to burn anything that can be burned alone or along with conventional fuels. Industrial boilers have different purposes in different industries and hence their operations are transient. Therefore, industrial boilers have much lower annual operating load or capacity factors than utility boilers. Utility boilers, on the other hand, generate steam at a constant rate to power turbines that produce electricity. Therefore, a utility boiler operates at a steady state rate close to its maximum capacity.

\section{MERCURY EMISSIONS CONTROL}

Controlling $\mathrm{Hg}$ emissions from boilers involves three separate steps; pre-combustion control, in-furnace control options, and post-combustion control options. Precombustion control options include coal cleaning and chemical addition while in-furnace control options include low excess air combustion, ammonia injection, and urea injection. The third controlling option, which takes place outside the combustion chamber, generally involves the use of selective catalytic reduction (SCR), electrostatic precipitators (ESP), fabric filters (FF), and mechanical separators (MS). Some power plants also use cold-side electrostatic precipitators (ESP-Cold Side), hot-side electrostatic precipitators (ESP-Hot Side), and particle scrubbers (PS). Plants use one or a combination of these post-combustion equipment options to reduce $\mathrm{NOx}, \mathrm{SO}_{2}$, and $\mathrm{PM}$. $\mathrm{Hg}$ is also captured through these equipment as a co-benefit, although the degree of benefit varies depending on the type of coal burned and the control technology configuration [8]. EPA's Mercury ICR revealed that plants employing PM controls experienced $\mathrm{Hg}$ reduction from no reduction to more than $100 \%$. A combination of ESP-Hot Side and FGD exhibited the highest average levels of mercury reductions, about $106 \%$ and $46 \%$ from bituminous and low rank coal, respectively [10]. FF alone showed better efficiency in $\mathrm{Hg}$ reduction when compared with other control technologies used alone. EPA's Mercury ICR also found that plants using both $\mathrm{PM}$ and $\mathrm{SO}_{2}$ controls achieved 0 to $98 \% \mathrm{Hg}$ emissions reduction. Some $\mathrm{Hg}$ specific emissions control methods are also used at present. Activated Carbon Injection (ACI) methods inject powdered activated carbon into the flue gas in a location before ESP or FF. The powdered carbon binds with $\mathrm{Hg}$ and PM in the flue gas and is subsequently captured by the PM reduction devices [12]. This method, however, would result in a significant increase in the cost of electricity from coal-fired power plants [3].

\section{SURVEY METHODOLOGY}

It was decided during the research project to collect boiler data through the use of a survey collection instrument. The survey contained two parts: identifying information and the necessary data. The items included in the survey were determined based upon appropriate input from boiler owners and operators, CIBO, and the U.S. Department of Energy (DOE). The data items were selected based upon their necessity for calculating the resultant information for the study. The survey form was distributed, with the assistance of the CIBO during 2004, to appropriate members of CIBO and other firms, whom it was felt would form a sufficiently large population for the data collection process. It was anticipated that this study would be able to obtain a large enough sample of data from this identified population to generate significant results and conclusions from the study. The final form of the survey is also available as supplementary material with this paper.

\section{RESULTS AND DISCUSSIONS}

There were completed survey forms returned with data covering 232 boilers at 118 plants owned by twenty-five companies. Eighty-seven boilers out of these 232 boilers qualified to be included in the study based on the parameters identified in the survey form. Test results from these eightyseven boilers have been presented in the following paragraphs.

\section{Distribution of Boilers}

Out of eighty-seven boilers reported in this survey, sixtytwo units were stoker units, twenty-two boilers were pulver- 
ized units, two were fluidized bed combustors, and one was a cyclone unit. All pulverized boiler units used bituminous coal while fifty-nine of the stoker units and two of the fluidized bed combustors also used bituminous coal. Two stoker units and one cyclone type boiler used sub-bituminous coal and the remaining stoker unit used waste coal.

Geographically, boilers selected in this analysis came from six EPA regions as shown in Fig. (1). The majority of these boilers belonged to EPA region \# 5, which constituted Indiana, Minnesota, Illinois, Ohio, Michigan, and Wisconsin. All these boilers used eastern bituminous coal. Eighteen boiler units were located in EPA Region \# 4, which included Kentucky, Tennessee, Mississippi, and Alabama. These boilers also used eastern bituminous coal. On a state by state comparison, Michigan had the largest representation with fifteen boilers, followed by Tennessee with thirteen boilers.

These boilers were also grouped according to the purposes they served, by their Standard Industrial Classification (SIC) code as shown in Table 1. Twenty-one boilers reported in this survey were used in the transportation equipment industries. Twelve boilers were used in chemical and allied products and ten boilers were used in organic chemical industries. Eleven boilers in this survey were used by universities. The remaining thirty-three boilers were used by salt manufacturers, prisons, hospitals, corn mills, paper mills, synthetic rubber manufacturers, pesticide and agricultural chemicals industries, electric services, combination utilities, and steam and air conditioning suppliers.

\section{Mercury Content}

Coal analysis performed by the facility owners yielded $\mathrm{Hg}$ contents in their fuel as a ratio of pounds of mercury to trillion $\left(10^{12}\right)$ British thermal units (tBtu) of the fuel burned. Sufficient data for appropriate analysis was possible for Eastern Bituminous coal only. The amount of $\mathrm{Hg}$ in this type of coal ranged from $1.53 \mathrm{lb} / \mathrm{tB}$ tu to $13.64 \mathrm{lb} / \mathrm{tBtu}$ with an average value of $7.88 \mathrm{lb} / \mathrm{tBtu}$ and a standard deviation of $3.32 \mathrm{lb} / \mathrm{tBtu}$. Fig. (2) presents a graphical representation of $\mathrm{Hg}$ content in Eastern Bituminous coal. It was observed that some coal analysis yielded $\mathrm{Hg}$ amounts well over the NESHAP standards of $9.0 \mathrm{lb} / \mathrm{tBtu}$ for existing large solid fuelfired boilers.

\section{PM Control Technologies}

Boilers reported in this survey used a variety of postcombustion particulate control devices. Out of twenty-two pulverized coal-fired boilers, eight used ESP while six used FF and six used ESP-Hot Side as shown in Fig. (3). The remaining two used ESP with cyclones. Out of the sixty-two stoker-fired boilers, twenty-six ICI boilers used FF while twenty boilers used MS as presented in Fig. (4). Five of them used ESP while seven of them used FF's with cyclone. The remaining four ICI boilers used a combination of cyclone and ESP and PS.

\section{Mercury Capture by Existing Post Combustion Control Technologies}

Table 2 presents the average $\mathrm{Hg}$ capture by existing post combustion control technologies. It was found that pulverized coal-fired boilers with FF were more effective than boilers equipped with ESP in capturing mercury. This is reasonable because filter cake in FF acts as a fixed bed reactor and contributes to greater homogeneous oxidation and

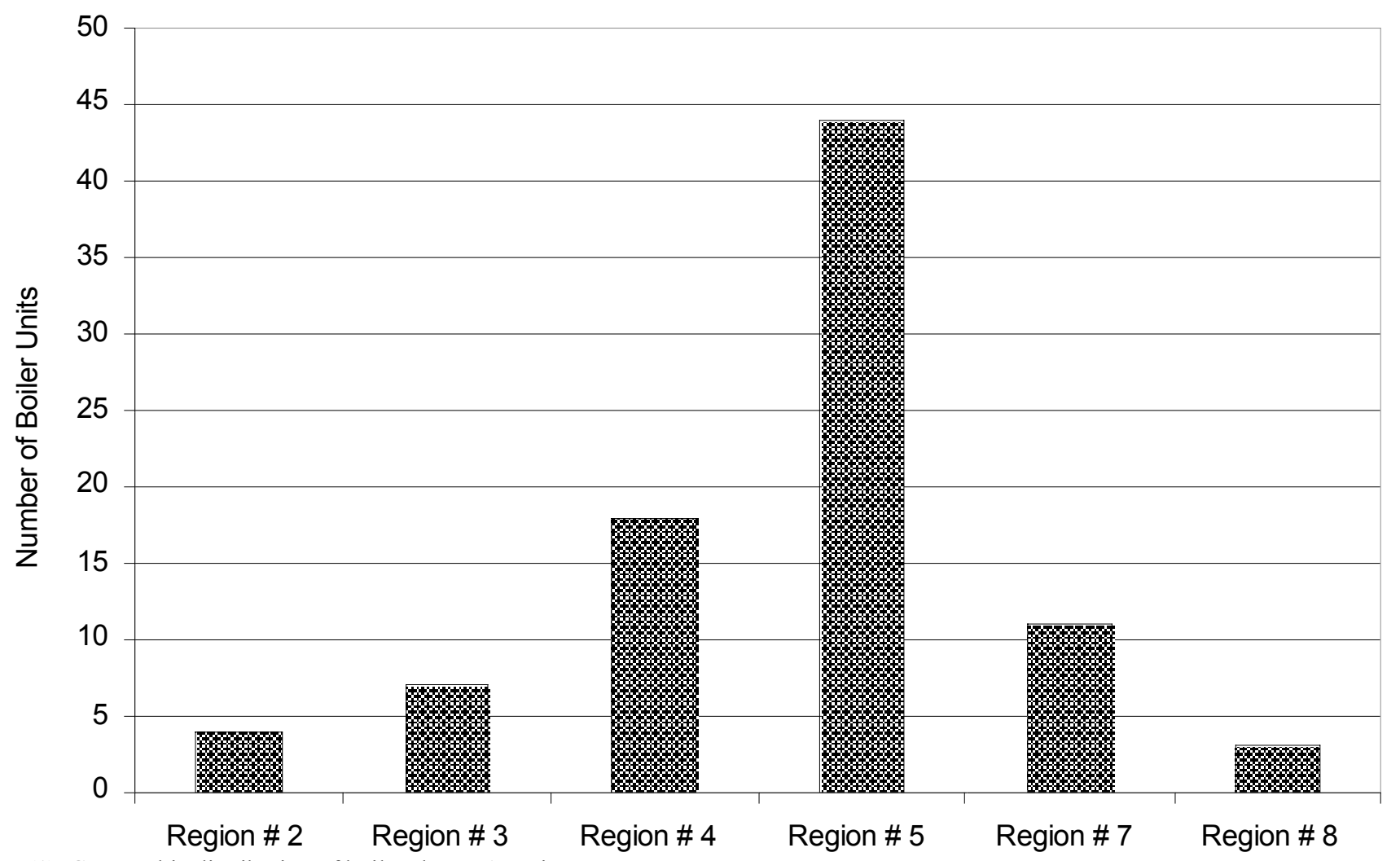

Fig. (1). Geographic distribution of boilers by EPA region. 
Table 1. Distribution of Boilers by Standard Industrial Classification (SIC) Code and their Purpose

\begin{tabular}{|c|c|c|c|c|c|c|}
\hline \multirow{2}{*}{ Primary SIC Code } & \multirow{2}{*}{ Examples of Reporting Entities } & \multicolumn{5}{|c|}{ Number of Boilers Reporting } \\
\hline & & Pulverized Coal & $\begin{array}{l}\text { Cyclone } \\
\text { Fired }\end{array}$ & $\begin{array}{c}\text { Fluidized } \\
\text { Bed Combustor }\end{array}$ & $\begin{array}{l}\text { Stoker } \\
\text { Fired }\end{array}$ & $\begin{array}{l}\text { Total Number of } \\
\text { Boilers Reported }\end{array}$ \\
\hline 28 & Chemical \& Allied Products & 6 & - & - & 6 & 12 \\
\hline 99 & Prison (non-classifiable establishment) & - & - & - & 3 & 3 \\
\hline 806 & IPP or Hospital & - & - & - & 2 & 2 \\
\hline 2046 & Wet Corn Milling & 3 & - & - & 5 & 8 \\
\hline 2621 & IPP - Paper Mill & - & - & - & 2 & 2 \\
\hline 2799 & Salt Manufacturer & - & - & - & 7 & 7 \\
\hline 2822 & Synthetic Rubber Manufacturer & 2 & - & - & - & 2 \\
\hline 2869 & Industrial Organic Chemicals & 8 & - & - & 2 & 10 \\
\hline 2879 & Pesticide and Agricultural Chemicals & - & - & - & 2 & 2 \\
\hline 3700 & $\begin{array}{l}\text { Motor Vehicle \& Parts Manufacturer } \\
\text { (Transportation Equipment) }\end{array}$ & - & - & 1 & 20 & 21 \\
\hline 4911 & Electric Services & - & - & - & 1 & 1 \\
\hline 4939 & Combination Utilities (gas, water) & 2 & - & - & 1 & 3 \\
\hline 4961 & Steam and Air Conditioning Supplier & 1 & - & - & 2 & 3 \\
\hline 8221 & University & - & 1 & 1 & 9 & 11 \\
\hline Total Number Reporting & & 22 & 1 & 2 & 62 & 87 \\
\hline
\end{tabular}

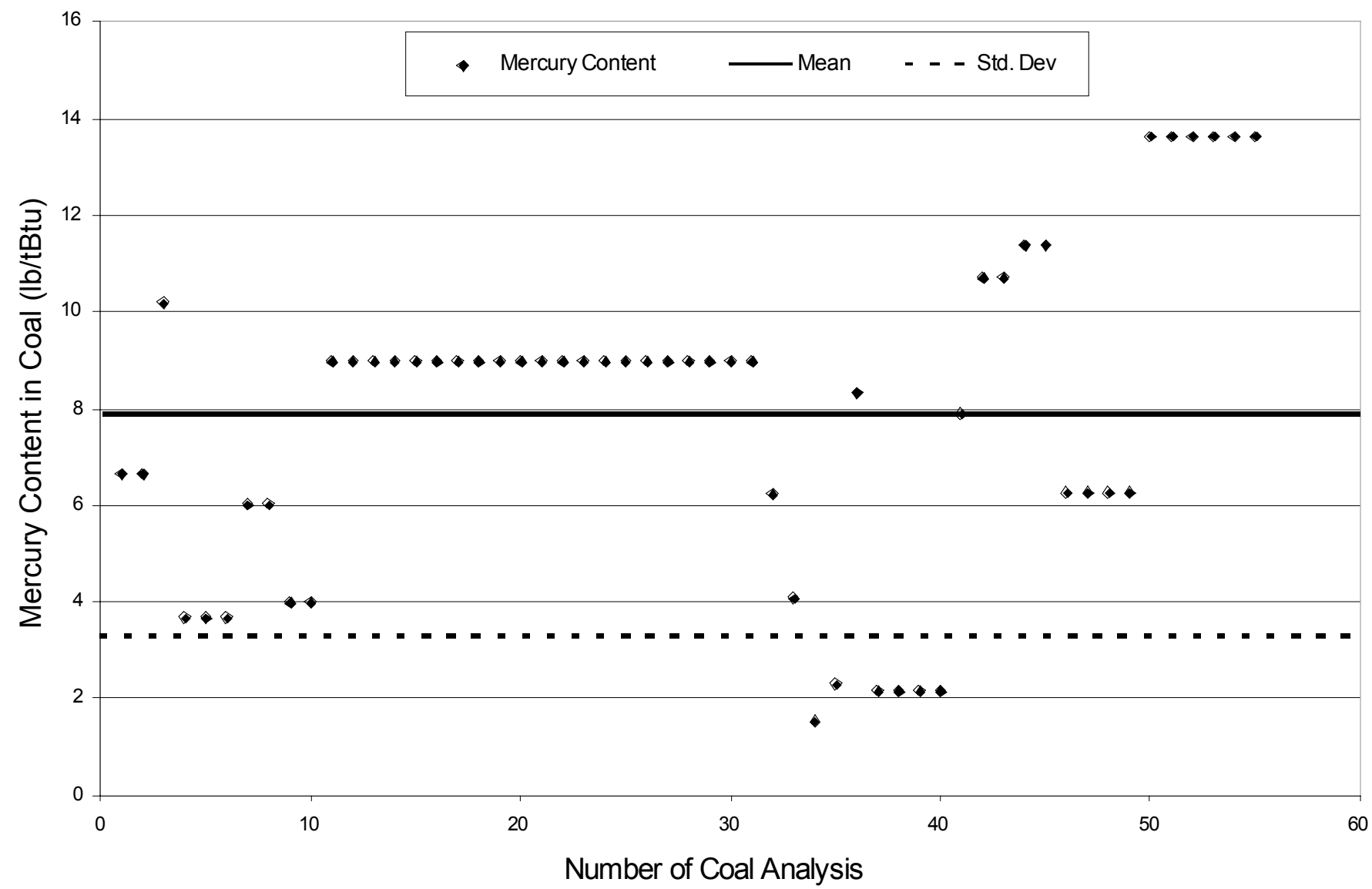

Fig. (2). Mercury content in eastern bituminous coal used in ICI boilers. 


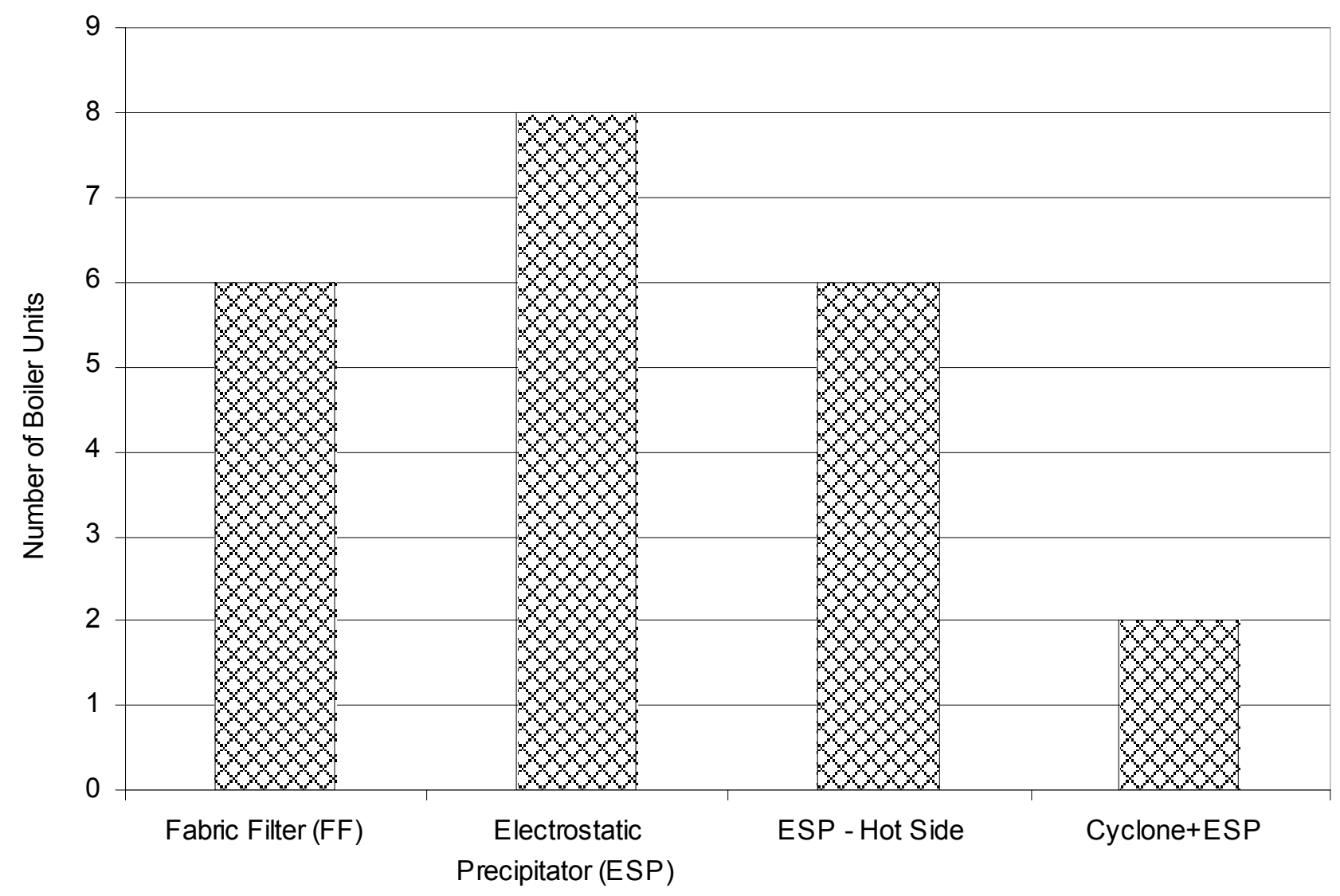

Fig. (3). Type of particulate control devices used by twenty-two pulverized coal-fired boilers.

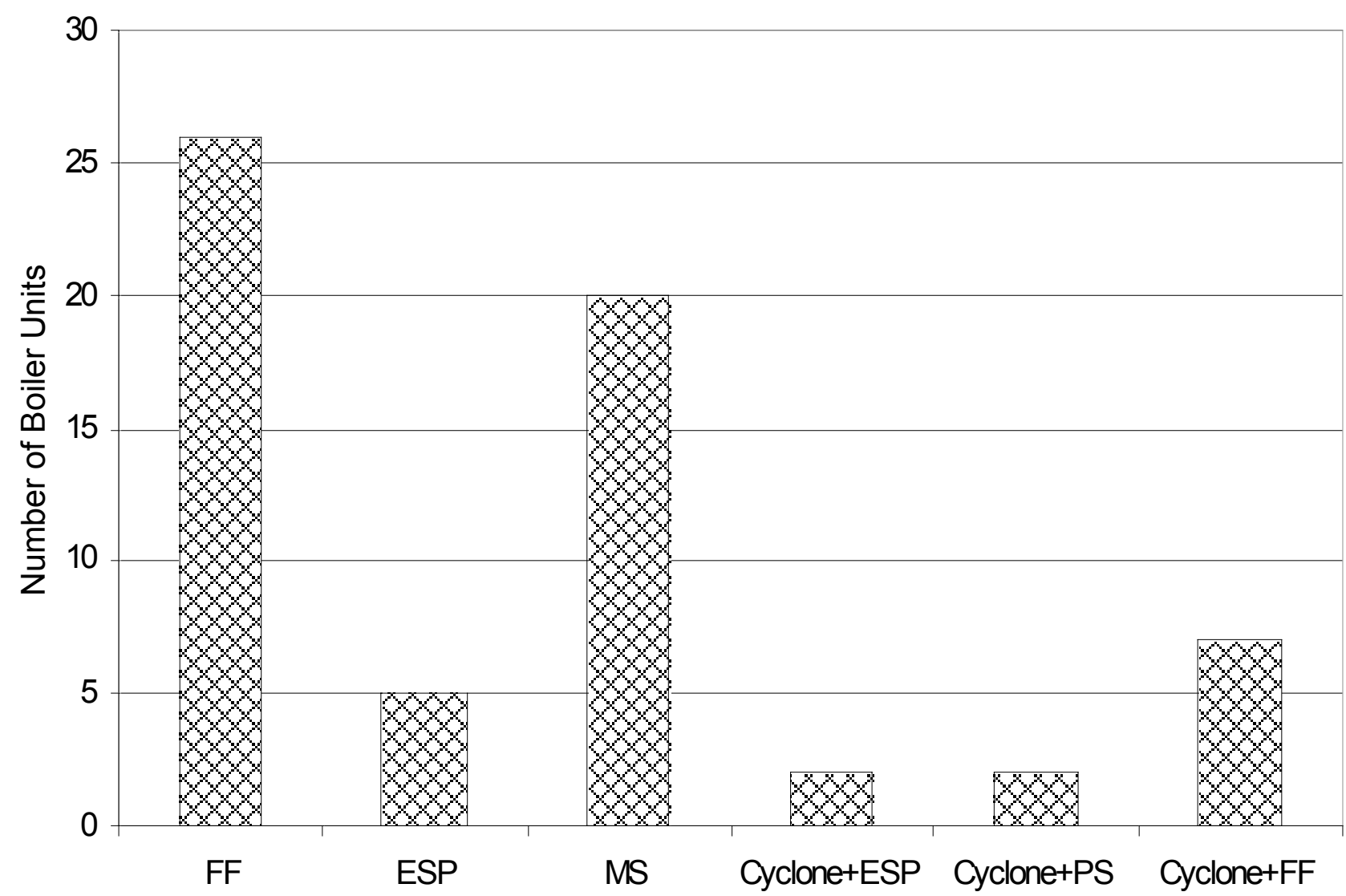

Fig. (4). Particulate control devices used by stoker-fired boilers. 
Table 2. Average Mercury Capture by Existing Post Combustion Technologies

\begin{tabular}{|c|c|c|c|}
\hline \multirow{4}{*}{ Post Combustion Control Strategy } & \multirow{4}{*}{ Post Combustion Emission Control Device } & \multicolumn{2}{|c|}{ Average Mercury Capture by Control Configuration } \\
\hline & & \multicolumn{2}{|c|}{ Coal Burned in ICI Boiler Units } \\
\hline & & \multicolumn{2}{|c|}{ Bituminous } \\
\hline & & Stoker Fired & Pulverized Coal Fired \\
\hline \multirow{3}{*}{ PM Control Only } & Electrostatic precipitators (ESP) & $-155.6 \%$ & $5.7 \%$ \\
\hline & Fabric Filters (FF) & & $96.4 \%$ \\
\hline & Mechanical Separators (MS)+FF & $45.8 \%$ & \\
\hline Wet $\mathrm{SO}_{2}$ Scrubber System & MS+ Venturi Wet Scrubbers (VWS) & $-4.0 \%$ & \\
\hline
\end{tabular}

adsorption of $\mathrm{Hg}$ [8]. These results supported the findings of the EPA's Mercury ICR. The negative emission reductions shown for stoker-fired boilers presented cases for which the outlet $\mathrm{Hg}$ concentration was higher than that of the inlet concentration. This was believed to result from one or a combination of factors. For example, negative emission reductions could have occurred when temperature changes within the test unit increased the desorption of $\mathrm{Hg}$, ESP rapping cycles resulted in the re-entrainment of $\mathrm{Hg}$, or small differences between inlet and outlet $\mathrm{Hg}$ concentrations were not accurately quantified because of imprecision in the measurement instruments.

\section{CONCLUSIONS}

$\mathrm{Hg}$ emissions data were considered in this research for eighteen different boiler units, which included sixteen stoker-fired boilers and two pulverized coal-fired boilers. It was found that ten out of the eighteen boiler units would have passed the present NESHAP $\mathrm{Hg}$ emissions standards for existing large boilers. Even though coal analyses were available for fifty-five of the original eighty-seven surveyed boiler units, $\mathrm{Hg}$ contents in the coal used were not available for all of the eighteen boilers discussed here. Both of the pulverized coal-fired boilers had stack $\mathrm{Hg}$ emissions below NESHAP standards for existing boilers. One pulverized and four stoker-fired boilers had $\mathrm{Hg}$ emissions below NESHAP standards for new boilers. The lowest $\mathrm{Hg}$ emission was observed for one stoker-fired unit employing a MS in series with a FF along with wet $\mathrm{SO}_{2}$ scrubbing and one pulverized coal-fired unit employing just a FF.

Emissions results and coal analysis showed that $\mathrm{Hg}$ emissions were affected by the type of coal used and hence its $\mathrm{Hg}$ content, type of particulate control technique used, and the type of control devices used by the boilers. Analysis of two boilers from the same facility, but employing different boiler and particulate control devices, revealed that control technique and control device could have produced different $\mathrm{Hg}$ emissions. Two boilers, with the same heat input rate and burning the similar coal, yielded different $\mathrm{Hg}$ emissions.

The lack of completeness in $\mathrm{Hg}$ emissions data and corresponding coal analysis data does not allow for any concrete conclusions from the current survey. The effect of fuel type, control technology, and control device on $\mathrm{Hg}$ emissions was observed. Additional data covering a wider range of boiler type, fuel type, and control device type will help to better quantitatively understand the extent to which each of these factors contribute to $\mathrm{Hg}$ emissions reduction.

\section{DEFINITIONS, ACRONYMS, ABBREVIATIONS}

ACI $=$ Activated Carbon Injection

APCD $=$ Air pollution control devices

Btu $=$ British thermal units

CAA $=$ Clean Air Act

CAIR $=$ Clean Air Interstate Rule

CAMR $=$ Clean Air Mercury Rule

$\mathrm{CIBO}=$ Council of Industrial Boiler Owners

$\mathrm{CO}_{2}=$ Carbon dioxide

CWA $=$ Clean Water Act

DOE = U.S. Department of Energy

ESP $=$ Electrostatic precipitators

$\mathrm{FF} \quad=$ Fabric filters

FGD $\quad=$ Flue gas desulfurization

HAP $=$ Hazardous air pollutants

$\mathrm{Hg} \quad=$ Mercury

$\mathrm{HgCl}_{2}=$ Mercuric chloride

ICI = Industrial, commercial, and Institutional Boilers

ICR $=$ Information Collection Request

MACT = Maximum achievable control technology

MS $=$ Mechanical separators

NESHAP $=$ National emission standards for hazardous air pollutants

NOx $\quad=$ Oxides of nitrogen

$\mathrm{PM} \quad=$ Particulate matter

PS $\quad=$ Particle scrubbers

$\mathrm{SCR}=$ Selective catalytic reduction

SIC $=$ Standard Industrial Classification

$\mathrm{SO}_{2}=$ Sulfur dioxide

USEPA = U.S. Environmental Protection Agency

VWS $=$ Venturi Wet Scrubber

WVU = West Virginia University 


\section{ACKNOWLEDGEMENTS}

The authors would like to express their gratitude to the U.S. Department of Energy (DOE) for funding this project. The authors would also like to thank the Council of Industrial Boilers Owners (CIBO), all who participated in this survey, and to Dr. Prakash Gajendran, for his contribution.

\section{SUPPLEMENTARY MATERIAL}

This article also contain supplementary data and it can be viewed at www.bentham.org/open/towmj

\section{REFERENCES}

[1]

"Energy Information Administration (EIA), Generation and Consumption of Fuels for Electricity Generation", Electric Power Monthly, July 2006, Available: http://www.eia.doe.gov/cneaf/ele ctricity/epm/epm sum.html

[2] J. Ravi, "Coal-Fired Power Plants - Science, Technology, and Environmental Policy Issues", Clean Technol. Environ. Policy, vol. 6, pp. 73-74, February 2004.

[3] C. E. Romero, Y. Li, H. Biligren, N. Sarunac, and E. K. Levy, "Modification of Boiler Operating Conditions for Mercury Emissions Reductions in Coal-Fired Utility Boilers", Fuel, vol. 85, pp. 204-212, January 2006.

[4] T. M. Sullivan, F. D. Lipfert, S. M. Morris, and S. Renninger, "Assessing the Mercury Health Risks Associated with Coal-Fired
Power Plants: Impacts of Local Depositions", Proc. Air Qual. IV Conf., Arlington, VA, September 2003.

[5] J. Kilgroe, C. Sedman, R. Srivastava, J. Ryan, C. Lee, and S. Thoreloe, "Control of Mercury Emissions from Coal-Fired Electric Utility Boilers: Interim Report”, EPA-600/R-01-109, U.S. Environ. Protect. Agency, April 2002.

[6] U.S. Environmental Protection Agency, "Mercury Study Report to Congress", EPA-452/R-97-003, 1997.

[7] U.S. Environmental Protection Agency, Code of Federal Regulations (CFR) 40, Part 63, Federal Register/ vol. 70, no. 248, December 28,2005

[8] R. K. Srivastava, N. Hutson, B. Martin, F. Princiotta, and J. Staudt, "Control of Mercury Emissions from Coal-Fired Electric Utility Boilers -An Overview of the Status of Mercury Control Technologies", Environ. Sci. Technol., vol. 40, pp. 1385-1393, March 2006.

[9] U.S. Environmental Protection Agency, "Mercury: Controlling Power Plant Emissions: Controlling Mercury with Existing Controls", Available: http://www.epa.gov/mercury/control emissions/ tech_exist.htm

[10] C. L. Senior, "Behavior of Mercury in Air Pollution Control Devices on Coal-Fired Utility Boilers", Power Production in the $21^{\mathrm{st}}$ Century: Impacts of Fuel Quality and Operations, Engineering Foundation Conference, Oct-Nov 2001.

[11] "Energy Efficiency and Industrial Boiler Efficiency - An Industry Perspective," Counc. Ind. Boiler Owners (CIBO), March 2003.

[12] "Mercury: Controlling Power Plant Emissions: Mercury Specific", U.S. Environmental Protection Agency, Available: http://www.epa. gov/mercury/control_emissions/tech_exist.htm 